See discussions, stats, and author profiles for this publication at: https://www.researchgate.net/publication/330312238

\title{
Investigating the Effects of Tourist Engagement on Satisfaction and Loyalty
}

Article in Service Industries Journal · January 2019

DOI: 10.1080/02642069.2019.1570152

\section{CITATION}

1

4 authors:

S. Mostafa Rasoolimanesh

Taylor's University

73 PUBLICATIONS 550 CITATIONS

SEE PROFILE

Florian Schuberth

University of Twente

26 PUBLICATIONS 43 CITATIONS

SEE PROFILE

\section{READS}

329

(2) Shuhaida Md Noor

Universiti Sains Malaysia

24 PUBLICATIONS 138 CITATIONS

SEE PROFILE

(2) Mastura Jaafar

Universiti Sains Malaysia

172 PUBLICATIONS 1,076 CITATIONS

SEE PROFILE

Some of the authors of this publication are also working on these related projects:

Special issue from Journal of Hospitality and Tourism Technology entitled "Partial Least Squares (PLS) in Hospitality and Tourism Research" View project

Application of Partial Least Squares - Structural Equation Modeling (PLS-SEM) in Tourism and Hospitality Research View project 


\title{
Investigating the Effects of Tourist Engagement on Satisfaction and Loyalty
}

\author{
S. Mostafa Rasoolimanesh \\ School of Hospitality, Tourism and Events \\ Taylor's University; Subang Jaya; Malaysia \\ rasooli1352@yahoo.com \\ mostafa.rasoolimanesh@taylors.edu.my \\ Shuhaida Md Noor \\ School of Communication \\ Universiti Sains Malaysia, 11800, Penang \\ shuhaida@usm.my
}

Florian Schuberth,

Faculty of Engineering Technology, University of Twente,

P.O. Box 217, 7500 AE Enschede, The Netherlands

f.schuberth@utwente.nl

\author{
Mastura Jaafar \\ School of Housing, Building, and Planning \\ Universiti Sains Malaysia, 11800, Penang \\ masturaj@usm.my
}

Acknowledgement: The authors would like to extend their appreciation to the Ministry of Higher Education, Malaysia and Universiti Sains Malaysia (USM) for the grant entitled Small Heritage Tourism Destination: An Explanatory Model of Small Heritage Tourism Experience [Grant No. 203.PCOMM.6711579] that makes this paper possible. 


\title{
Investigating the Effects of Tourist Engagement on Satisfaction and Loyalty
}

\begin{abstract}
This paper examine the concept of tourist engagement modeled as a second-order composite in the context of a heritage destination in Malaysia. In doing so, this study investigates the direct and indirect effects of tourist engagement through satisfaction on destination loyalty. Data was collected from tourists visiting Kinabalu National Park, Sabah, Malaysia. To investigate tourist engagement, this study employs Confirmatory Composite Analysis in combination with the latest version of Partial Least Squares Path Modeling (PLS-PM) known as consistent Partial Least Squares. The findings strongly support to model tourist engagement as a second-order composite and show a strong positive effect for tourist engagement on satisfaction and tourists' destination loyalty. Moreover, a strong indirect effect of tourist engagement on loyalty through satisfaction is revealed. This study has a number of practical implications for local authorities to sustain tourism development in the Kinabalu National Park.
\end{abstract}

Keywords: Tourist engagement, satisfaction, loyalty, composite construct, confirmatory composite analysis

\section{Introduction}

Several studies have investigated the concept of consumer/tourist engagement towards a tourism destination as an important factor influencing tourist loyalty and revisit intentions (Bolton, 2011; Brodie, Hollebeek, Jurić, \& Ilić, 2011; Patterson, Yu, \& de Ruyter, 2006; Vivek, Beatty, \& Morgan, 2012). These studies have explored this issue from different perspectives, such as relationship marketing theory and organizational behavior (So, King, \& Sparks, 2014; Taheri, Jafari, \& O’Gorman, 2014). However, very few studies have examined consumer/tourist engagement and its operationalization. For example, So et al. (2014) modeled consumer engagement as a second-order reflective construct measured by five dimensions, 
namely identification, enthusiasm, attention, absorption, and interactions based on both psychological and behavioral perspectives. Taheri et al. (2014), on the other hand, consider tourist engagement as an artifact, and therefore modeled it as a formative (composite) construct.

In the current study, we also model consumer/tourist engagement as a composite, however in contrast to Taheri et al. (2014) and So et al. (2014), we model it as a second-order composite following the most recent guidelines. To the best of our knowledge, this is the first time that this construct has been articulated in this manner in the tourism and hospitality literature. While many studies have emphasized the important role of tourist engagement in the development of tourism destinations, with studies having investigated both the antecedents and consequences of tourist engagement (Bowden, 2009; Bryce, Curran, O’Gorman, \& Taheri, 2015; Leckie, Nyadzayo, \& Johnson, 2016), only few empirical studies exist that assess consumer/tourist engagement from the measurement theory perspective (So et al., 2014; Taheri et al., 2014). However, if a study fails to measure tourist engagement correctly, it may produce inaccurate results with respect to the effects of the antecedents and consequences of tourist engagement on tourism destinations (Sarstedt et al. 2016).

Several studies have investigated the consequences of tourist engagement, including satisfaction and tourist loyalty (Bowden, 2009; Bryce et al., 2015; Leckie et al., 2016; So, King, Sparks, \& Wang, 2016). The current study investigates the effect of tourist engagement modeled as a second-order composite on satisfaction and loyalty in the context of the Kinabalu National Park World Heritage Site (WHS). Moreover, this study examines the mediating role of tourist satisfaction between tourist engagement and loyalty to compare the importance of the direct effect of tourist engagement on loyalty with the indirect effect through satisfaction.

Therefore, the objectives of the current study are to: (a) assess tourist engagement as a secondorder composite, (b) examine the effect of tourist engagement on satisfaction and loyalty, and 
(c) assess the mediating role of satisfaction between tourist engagement and loyalty. Following this introduction, this paper includes a review of the tourist engagement literature, exploring its effects on satisfaction and loyalty. The methodology section of this paper explains the study area, data collection process, and data analysis. The results section presents the findings of the assessment measurement model and structural model using the partial least squares - path modeling (PLS-PM), and discuss these results in relation to the literature review. This paper concludes by considering the theoretical contributions, practical implications, and limitations of this study, and provides several recommendations for future research.

\section{Literature Review}

\section{Tourist Engagement}

Although the concept of consumer/tourist engagement had been examined across several studies (e.g., Bolton, 2011; Brodie et al., 2011; Patterson et al., 2006; Vivek et al., 2012), it was not fully explored (So et al., 2014). Therefore, more recent studies have considered consumer/tourist engagement from various perspectives (So et al., 2016; Taheri et al., 2014). Vivek et al. (2012), for example, investigated consumer/tourist engagement from an expanded domain of relationship marketing theory, focusing on interactive consumer experiences (Brodie, Ilic, Juric, \& Hollebeek, 2013). From this perspective, consumer/tourist engagement refers to the interactive experiences of consumers/tourists with other stakeholders and the environment, which has subsequently become the core of the tourism marketing system (Brodie et al., 2013). From the organizational behavior perspective, employment engagement is a stable concept that can help to clarify and identify consumer engagement (So et al., 2014). Employment engagement focuses on attention, absorption, and identification as the main psychological elements of engagement (Rothbard, 2001; So et al., 2014). Therefore, from the organizational behavior perspective, consumer/tourist engagement is primarily concerned with psychological aspects, such as cognitive and emotional domains. Combining these 
perspectives, consumer/tourist engagement can be defined as a concept comprising cognitive, emotional, and interactive behavioral activities (Brodie et al., 2013; Hollebeek, 2011; Patterson et al., 2006). Brodie et al. (2011) suggests that consumer/tourist engagement should include consumers' psychological and behavioral participation, since lacking of one of these aspects would imply that some parts of consumer/tourist engagement are missing. Consequently, an omission of psychological aspects or behavioral activities unlikely provides sufficient insights to properly investigate consumer engagement (So et al., 2014, 2016). However, neither psychological aspects nor behavioral activities alone reveal the actual level of consumer engagement. True engagement must reflect an enduring psychological connection, plus ongoing interactive behavioral participation with the object (So et al., 2014). Therefore, consumer/tourist engagement can be regarded as a composite comprising these different aspects (So et al., 2014, 2016).

\section{Tourist Engagement modeled as a Second-Order Composite}

According to the five-dimensional consumer/tourist engagement framework as proposed by So et al. (2014), enthusiasm represents an individual's "strong level of excitement or zeal" and interest in a brand/destination (Vivek, 2009, p. 60). So et al. (2014) observed that enthusiasm "represents an individual's strong level of excitement and interest regarding the focus of engagement, such as a brand" (p. 308). Tourists who are engaged with a tourism destination have passionate and enthusiastic feeling about the destination. Therefore, items such as: "I am heavily into this tourism site"; "I am passionate about this tourism site"; and "I am enthusiastic about this tourism site" measure this aspect of tourist engagement.

Attention refers to a consumer/tourist's level of focus, consciously or subconsciously, on the brand/destination. Persistent attention towards a brand/destination is likely to lead to higher levels of engagement (Lin, Gregor, \& Ewing, 2008; Scholer \& Higgins, 2009). Tourists who 
are interested in finding more information about a destination, such as through news and advertisements, are more engaged with a destination pay more attention (So et al., 2014). Therefore, items such as: "I pay a lot of attention to anything about this tourism site"; "Anything related to this tourism site grabs my attention"; and "I concentrate a lot in my visit at this tourism site" can be used to measure the attention.

Absorption goes further than attention, referring to an all absorbing level of consumer/tourist focus on a brand/destination (Schaufeli, Salanova, González-Romá, \& Bakker, 2002). Such absorption is regarded as a positive trait in which consumers are contently absorbed in or with the brand/destination, even if they are unaware of how much time they have devoted to the brand (Scholer \& Higgins, 2009). Therefore, an engaged tourist is intently focused and happy when visiting a site, such that they can easily lose track of time (So et al., 2014). The following items are used to measure this dimension of tourist engagement with a destination: "When I am interacting with the tourism site, I forget everything else around me"; "Time flies when I am interacting with the tourism site"; "When I am interacting with the tourism site, I get carried away"; and "When interacting with the tourism site, it is difficult to detach myself".

Interaction is fundamental to consumer/tourist engagement and involves sharing and exchanging ideas, thoughts, and feelings about one's experiences with the brand/destination, and other consumers, residents, or stakeholders, in the case of a heritage destination (Vivek, 2009). These interactions between tourists, local community members, and other stakeholders is supported by the brand community literature (Muniz \& O'Guinn, 2001). The interaction aspect of tourist engagement refers to behavioral activities that involved effective interactions with the destination (So et al., 2014). To measure this aspect of tourist engagement perspective, the following items are used: "I am someone who enjoys interacting with a like-minded tourism community"; "I am someone who likes to actively participate in tourism site community 
discussions"; and "In general, I thoroughly enjoy exchanging ideas with other people in the tourism site community".

Consumer/tourists will identify with certain brands/destinations, particularly with those that match their self-image (Bagozzi \& Dholakia, 2006). This notion draws upon social identity theory, where individuals have both a personal identity and a social identity, which can be measured by items such as: "When someone criticizes this tourism site, it feels like a personal insult"; "When I talk about this tourism site, I usually say 'we' rather than 'they' because the identity of the site suites me"; and "When someone praises this tourism site, it feels like a personal compliment".

Few studies have explored the nature of the consumer/tourist engagement construct (So et al., 2014; Taheri et al., 2014). Among these, So et al. (2014) understood consumer/tourist engagement as a second-order reflective, while Taheri et al. (2014) modeled it as a unidimensional formative (composite) construct. In general, recent literature suggests that there are three different ways to operationalize constructs; namely reflective measurement model, causal-formative measurement model, and composite model (Bollen, 2011; Henseler, 2017). Determining the way of modeling a construct is a function of its nature and its associated items (Sarstedt et al., 2016). Items in a reflective measurement model are assumed to be manifestations of an underlying construct represented by a common factor (Bollen, 1989). Therefore, the items are highly correlated and theoretically interchangeable without altering the meaning of the construct. This way of operationalizing a construct is typically used for attitudes and abilities. Besides the reflective measurement of a construct, the causal-formative measurement has been established that reverses the relationship between the items and the unobservable underlying construct (Diamantopoulos, 2008). Therefore, items in a causalformative measurement model are not necessarily correlated, since each item measures one specific aspect of the construct (Diamantopoulos, 2006). Consequently, removing one item will 
likely alter the meaning of the construct (Rasoolimanesh \& Ali, 2018). Only recently, the composite model was introduced as a third way of construct modeling (Henseler, 2017). It can be used to model abstract human-made objects - so-called artifacts. The items in the composite model build the construct and are typically assumed to be free of measurement error. Hence, the construct scores adequately represent the underlying construct. However, similar to the causal-formative measurement model, dropping an item may alter the meaning of the underlying construct. In contrast to the causal-formative measurement, the relationship between the indicators and the construct is rather a definitorial than a causal one. Hence, second-order constructs that represent artifacts or are assumed to be made up by different dimensions can be modeled as second-order composite.

As explained earlier, the current study applies the five-dimensional consumer/tourist engagement framework proposed by So et al. (2014) including enthusiasm, attention, absorption, interactions, and identification to cover both psychological and behavioral perspectives. Hence, these dimensions represent different aspects of consumer/tourist engagement, an omission of each dimension provides insufficient insights to investigate consumer engagement (So et al., 2014, 2016). Therefore, in this study, the consumer/tourist engagement is modeled as a second-order composite that is formed by its five reflectively measured dimensions, where each dimension represents a unique part of tourist engagement.

\section{Tourist Engagement, Satisfaction, and Loyalty}

Several studies have investigated the antecedents and consequences of tourist engagement in different contexts (Bowden, 2009; Bryce et al., 2015; Leckie et al., 2016; So et al., 2016). Various factors, such as trust, commitment, customer value, customer equity, satisfaction, and loyalty have been identified and investigated as consequences of consumer engagement, with loyalty and satisfaction being among the most important ones (Bryce et al., 2015; So et al., 
2014). As a psychological process, consumer/tourist engagement includes cognitive and emotional domains and results in consumer satisfaction; while from a behavioral perspective, consumer/tourist engagement is indicated by customer loyalty towards a brand/object, which is reflected in their tendency to repurchase or revisit a destination (Bowden, 2009; Bryce et al., 2015). Satisfaction represents positive consumer/tourist feelings towards a brand or a destination; therefore, from a psychological perspective, consumer/tourist engagement has a positive effect on satisfaction (Bryce et al., 2015; Zhou, Zhang, \& Edelheim, 2013). Moreover, loyalty represents the willingness of consumer/tourist to re-buy/re-visit a brand product/destination consistently (So et al., 2016). Consumer/tourist engagement demonstrates deep commitment and connection with brand/destination, which can enhance the consumer/tourist feelings and behaviors (Hollebeek, 2011; So et al., 2014). An engaged tourist with a destination develops more favorable attitude, and therefore it is expected to be more interested to re-visit and more loyal towards a destination (Brodie et al., 2011; Vivek et al., 2012). Consequently, the following effects are hypothesized:

H1: Tourist engagement has a positive direct effect on tourist satisfaction towards a destination.

H2: Tourist engagement has a positive direct effect on tourist loyalty towards a destination.

In the context of tourism and destination marketing, and based on the theory of relationship marketing, a number of studies have investigated the positive effect of tourist satisfaction on loyalty (Bowden, 2009; Chi \& Qu, 2008; Gallarza \& Saura, 2006; Oliver, 1999; Yoon \& Uysal, 2005). Several previous studies demonstrated that if the tourists are satisfied with a destination, and tourism attractions, they are more willing to revisit and return to this destination (Chi \& Qu, 2008; Yoon \& Uysal, 2005). Satisfied tourists are loyal towards a destination and they are more likely to spread the positive word of mouth, share their positive experiences and 
recommend the destination to others (Chi \& $\mathrm{Qu}, 2008)$. In addition, traditionally satisfaction has been investigated as a mediator of marketing outcomes, such as loyalty and repurchase intension (Bowden, 2009). Therefore, the following effects are hypothesized:

H3: Tourist satisfaction towards a destination has a positive direct effect on loyalty.

H4: Tourist satisfaction towards a destination mediates the relationship between tourist engagement and loyalty.

Figure 1 shows the conceptual framework of the current study.

[Figure 1 about here]

\section{Methodology}

\section{Study Area}

The data for this study was collected at the Kinabalu National Park's main entrance. The main entrance is located $92 \mathrm{~km}$ from the urban center of Kota Kinabalu, the state capital of Sabah, Malaysia. The Kinabalu National Park is one of the most visited destinations in Malaysia, and is well-known in both domestic and international tourism circles due to its diversity of flora and fauna. The Kinabalu Park covers a protected area of $753.7 \mathrm{~km}^{2}$ (Rasoolimanesh, Jaafar, \& Tangit, 2018) and was inscribed as a national park in 1964, and as a World Heritage Site (WHS) by the United Nations Educational, Scientific, and Cultural Organization (UNESCO) in 2000. The main attractions in Kinabalu National Park are Mount Kinabalu, the diversity of flora and fauna, as well as the Poring Hot Spring, and Mesilau Nature Resort.

\section{Data Collection Process}

This study employs a quantitative research approach based on data collected by questionnaires. The question-statements in the questionnaire were adapted from So et al. $(2014,2016)$ to measure the different dimensions forming tourist engagement, and from Bryce et al. (2015) 
and So et al. (2016) to measure loyalty and satisfaction. Participants were asked to indicate their responses on a 5-point Likert scale ranging from 1 to 5, representing strongly disagree and strongly agree respectively. Data was collected at the main entrance to Kinabalu National Park. The respondents were visitors/tourists visiting Kinabalu National Park. During the process of distributing the questionnaire, the researchers struck up an informal conversation with potential respondents about their experience of visiting the site before asking them to complete the questionnaire. Therefore, non-probabilistic purposive sampling was applied to collect the data. In total, 208 questionnaires were completed by visitors/tourists to Kinabalu National Park. Among the respondents, 91 respondents (43.7\%) were male, and 117 respondents (56.3\%) were female. Regarding marital status, 110 respondents (52.9\%) were not married, while 98 respondents $(47.1 \%)$ were married. Most respondents $(n=173 ; 83.2 \%)$ were domestic Malaysian tourists, while only 35 respondents $(16.8 \%)$ were foreign tourists. In addition, the majority of respondents (74.5\%) were less than 35 years of age, while only $25.5 \%$ of respondents were middle aged or older. Most respondents $(n=165 ; 79.3 \%)$ had completed tertiary or higher education (e.g., undergraduate or postgraduate).

\section{Data Analysis}

To estimate our proposed model, this study employs PLS-PM (Wold, 1985) including its most recent developments such as consistent partial least squares (PLSc) (Dijkstra \& Henseler, 2015a). We choose PLS-PM, since in its current form it is a consistent composite-based estimator for structural equation models containing reflective, formative, and composite constructs (Dijkstra \& Henseler, 2015b), and it can be applied for different types of research (Henseler, 2018; Henseler, Müller, \& Schuberth, 2018). To assess the minimum required sample size in terms of statistical power, we used G*Power (Faul, Erdfelder, Buchner, \& Lang, 2009), indicating that a sample size of 146 observations is needed to achieve a statistical power 
of $95 \%$. Thus, a sample size of 208 observations is large enough to reliably detect effects when they indeed exit in the population.

To estimate and assess the second-order composite formed by first-order reflective constructs, we employed confirmatory composite analysis (Henseler et al., 2014; Schuberth, Henseler, \& Dijkstra, 2018). In doing so, we followed a three stage approach proposed by van Riel, Henseler, Kemény, and Sasovova, (2017). In the first stage, we estimated a structural model containing all constructs except tourist engagement. Moreover, all constructs were allowed to freely correlate. Thus, we ignored potential misspecifications in the structural model and fully focused on the measurement of the constructs. Since all constructs in this model were reflectively measured, i.e., modeled as common factors, we employed PLSc to obtain consistent estimates. In the second stage, we used the scores of the first-order constructs to estimate the model containing tourist engagement modeled as second-order composite, i.e., the scores of the first-order constructs were used as items for tourist engagement. The weights for this purpose were obtained by mode A. Finally, in the last stage, we correct for attenuation to obtain consistent path coefficient and weight estimates for the model from the second stage. In addition, we estimated a model where the second-order construct was operationalized as a common factor to obtain further empirical evidence for the second-order composite. For all estimations we used ADANCO (Henseler \& Dijkstra, 2015). Furthermore, the number of bootstrap runs was set to 999 and as inner weighting scheme, the path weighting scheme was employed.

\section{Results and Findings}

To assess the measurement model and the structural model, we followed the recently suggested guidelines for the use of PLS-PM in confirmatory and explanatory research (Müller et al. 2018; Henseler at al., 2016). Since the structural model consists of tourist engagement modeled as a 
second-order composite formed by its five dimensions - enthusiasm, attention, absorption, interaction, and identification (So et al., 2014), the model had to be assessed in several stages (van Riel et al., 2017). In the first stage, we assessed all constructs except tourist engagement, which were all modeled as reflective: satisfaction, loyalty, and the five dimensions of tourist engagement. In the second stage, we assessed the fit of the model containing the second-order composite. Finally, in the third stage, we assessed the structural model.

\section{Assessment of the Measurement Model}

In the first stage, we assessed the seven reflectively measured constructs, i.e., enthusiasm, attention, absorption, interaction, and identification as the dimensions of tourist engagement, as well as satisfaction and loyalty. In doing so, we run a confirmatory factor analysis (i.e., we estimated a model containing the seven constructs but with a saturated structural model). The test for overall model fit was not rejected $\left(d_{U L S}=0.3184, \mathrm{p}>.01\right)$. Moreover, the Standardized Root Mean Square Residual (SRMR) was below the recommended threshold of 0.08 (Hu \& Bentler, 1999) indicating an acceptable model fit. Hence, we obtained empirical evidence for the operationalized constructs. Moreover, indicator and construct reliability, convergent validity, and discriminant validity had to be established (Ali et al., 2018; Müller et al., 2018). To establish indicator reliability, the loading of each item on its associated construct should be higher than 0.7 ( Hair, Hult, Ringle, \& Sarstedt, 2017). In order to establish construct reliability, Dijkstra \& Henseler's $\rho_{A}$, Composite Reliability (CR), and the more commonly applied Cronbach's alpha coefficient should be larger than 0.7 ; and to establish convergent validity, the AVE for each construct should be larger than 0.5 (Fornell \& Larcker, 1981; Hair et al., 2017). Table 1 shows that all indicator loadings were higher than 0.7, and that Dijkstra and Henseler's $\rho_{A}, \mathrm{CR}$, as well as Cronbach's alpha exceeded 0.7 for all constructs in the first stage. These results indicate that the measurement models were internally consistent and reliable. Additionally, the results from Table 1 show that the AVEs were larger than 0.5 for all reflective 
constructs, thus indicating acceptable convergent validity. To assess discriminant validity, we applied the Fornell-Larcker criterion and the heterotrait-monotrait ratio of correlations (HTMT) (Fornell \& Larcker, 1981; Henseler, Ringle, \& Sarstedt, 2015). According to the Fornell-Larcker criterion, the AVE for a construct should be greater than its squared correlations with all other constructs to establish discriminant validity. For the HTMT, all values should be significantly below one. As a recommended threshold, a value of 0.85 or 0.9 has been established to provide sufficient evidence of discriminant validity (Henseler, Ringle, \& Sarstedt,, 2015; Voorhees, Brady, Calantone, \& Ramirez, 2016). Tables 2 and 3 show the results of the Fornell-Larcker criterion and HTMT. Although the AVE for Attention was smaller than its squared correlation with Absorption, we followed recent recommendation to rely on the HTMT instead of the Fornell-Larcker criterion to assess discriminant validity (Franke \& Sarstedt, in press). Moreover, all values of the HTMT were statistically significant smaller than 1 by means of the $95 \%$ percentile bootstrap confidence intervals. Hence, we concluded that discriminant validity is ensured.

[Table 1 about here]

[Table 2 about here]

[Table 3 about here]

Following van Riel et al. (2017), in the second stage, we assessed the fit of model containing the second-order composite, but without its first-order constructs. Again, the test for overall model fit was not rejected $\left(d_{U L S}=0.0218, \mathrm{p}>.01\right)$ and the SRMR was below the recommended threshold of 0.08 , indicating an acceptable model fit. To obtain further empirical evidence for the second-order composite, we additionally investigated the model fit of the same model but with the second-order construct modeled reflectively. In this case, the overall model fit significantly decreased. While the SRMR was still below 0.08 , the test for overall model fit 
was rejected $\left(d_{U L S}=0.0550, \mathrm{p}<.01\right)$. In line with the literature review and the characteristics of tourist engagement, our results led to the conclusion that the second-order construct was appropriately modeled by a composite.

To assess tourist engagement modeled as a second-order composite, three criteria were proposed: nomological validity, reliability, and weights (Henseler, 2016; Müller et al., 2018). While nomological validity had already been established by the previous test for overall model fit, we immediately focused on the composite reliability and the weights. Since, the secondorder composite is formed by the factor scores of the first-order constructs, its reliability had to be adjusted (van Riel et al., 2017). In our case, the reliability of the second-order composite was 0.9710 . Finally, the results in Table 1 present the weights used to build the second-order. All weights were significantly different from zero on a $1 \%$ significance level.

\section{Assessment of Structural Model}

In order to assess the structural model, traditionally the coefficients of determination $\left(R^{2}\right)$ of the endogenous constructs, the size and sign of the path coefficients, and the effect size $\left(f^{2}\right)$ should be considered (Ali et al., 2018; Müller et al., 2018). A value of 0.2 for the $R^{2}$ is commonly considered as high in the behavioral science (Rasoolimanesh, Jaafar, Kock, \& Ahmad, 2017). In addition, the path coefficient estimates should be statistically significant based on the percentile bootstrap confidence interval (Aguirre-Urreta \& Rönkkö, 2017) and their sign should be consistent with the associated hypothesis. For significant path coefficients, an effect size $\left(f^{2}\right)$ of $0.02,0.15$, or 0.35 , respectively, indicates a small, medium, or large effect size (Cohen, 1988).

Figure 2 shows values of 0.4615 and 0.6011 for the $R^{2}$ of satisfaction and loyalty, respectively. These values can be considered very high and acceptable. Moreover, Table 4 shows the results 
for the structural model supporting all hypotheses $(\mathrm{H} 1-\mathrm{H} 4)$. The results show a positive and significant effect of tourist engagement on satisfaction $\left(f^{2}=.857\right.$ and $\left.f^{2}=.178\right)$ and loyalty, as well as a positive and significant effect of satisfaction on loyalty $\left(f^{2}=.313\right)$. In addition, the results confirmed the significant mediating role of satisfaction between tourist engagement and loyalty. To assess the mediator, we evaluated the significance of the indirect effect using the percentile bootstrap confidence interval (Nitzl, Roldan, \& Cepeda, 2016).

[Figure 2 about here]

[Table 4 about here]

\section{Discussion}

The aim of this study was to assess tourist engagement operationalized as second-order composite composed of five reflectively measured dimensions, namely enthusiasm, attention, absorption, interaction, and identification from psychological and behavioral perspectives. In addition, this study examined the effect of tourist engagement on destination satisfaction and loyalty, and the mediating role of satisfaction between tourist engagement and loyalty. In doing so, this study followed the recent guidelines on the estimation and assessment of models containing constructs modeled as composite and common factor as well as second-order composites built by common factors the in the context of PLS-PM (Henseler et al., 2016; Müller et al., 2018; Rasoolimanesh \& Ali, 2018; van Riel et al., 2017). Several previous studies have identified tourist engagement as a multidimensional construct including psychological and behavioral aspects (Brodie et al., 2013; Hollebeek, 2011; Patterson et al., 2006; So et al., 2014, 2016). Additionally, previous studies have identified that tourist engagement includes psychological elements, such as cognitive and emotional aspects, as well as interactive behavioral activities with the destination (Brodie et al., 2013; Hollebeek, 2011; Patterson et al., 2006). These aspects together can be understood as tourist engagement, thus indicating that 
tourist engagement can be appropriately modeled as a composite (Henseler, 2017; Rasoolimanesh \& Ali, 2018; So et al., 2014). For the first time, the results of our study provided empirical evidence for tourist engagement modeled as second-order composite built by its five dimensions. Moreover, the results of the current study were consistent with those from previous studies.

Several previous studies have identified the positive and significant effects of consumer/tourist engagement on satisfaction and loyalty (Bowden, 2009; Bryce et al., 2015; So et al., 2014). The results of the current study were therefore in line with the findings of previous studies. However, our results also identified the direct effect of tourist engagement on satisfaction ( $\beta=0.6793$ ), which was much higher than the direct effect of tourist engagement on loyalty ( $\beta=0.3632$ ). Tourist engagement, of course, includes both psychological aspects and behavioral activities; the psychological elements, including cognitive and emotional aspects, influence tourists satisfaction, and the behavioral aspect affects tourists' loyalty towards the destination and their destination revisit intentions (Bowden, 2009; Bryce et al., 2015). The greater direct effect of tourist engagement on satisfaction compared to loyalty shows the greater importance of these psychological dimensions of tourist engagement compared to behavioral dimensions. Moreover, our study showed that tourist engagement has a non-negligible positive indirect effect on loyalty (0.3270).

\section{Conclusion}

To the best of our knowledge, this has been the first study that examined tourist engagement modeled as a second-order composite in the context of tourism. Proposing and validating the measurement structure of tourist engagement as a second-order composite can be considered a unique theoretical contribution of this study from measurement theory perspective. In addition, this study by applying confirmatory composite analysis approach in combination with PLS- 
PM and its recent developments makes a significant methodological contribution to the tourism study literature. Moreover, this study assessed the effect of tourist engagement on satisfaction and loyalty, confirming their practical and statistical significance. The effect of tourist engagement on satisfaction was found to be much higher than the effect of tourist engagement on loyalty. Furthermore, a positive indirect effect of tourist engagement on loyalty was found. Both of these findings make a significant theoretical contribution to the literature, confirming the important role of psychological aspects of tourist engagement, thus mediating tourist satisfaction and contributing to improved tourist loyalty and intentions to revisit. These findings also have a number of practical implications, suggesting that local authorities should focus on improving tourists' emotional and cognitive experiences, and the psychological aspects of tourist engagement if they want to improve tourist satisfaction, increase tourist loyalty, and encourage revisiting intentions. In addition, the findings showed that tourist engagement can directly influence tourist loyalty and revisiting intentions, although this is primarily a product of the behavioral aspects of tourist engagement. Therefore, improving the behavioral dimensions of tourist engagement, perhaps by promoting interactions between the tourist and the local community, as well as the tourist's involvement in destination-related activities, increases their loyalty and intentions to revisit. Consequently, local authorities should look to develop strategies to improve the involvement of tourists in destination-related activities, and to increase their interaction with other stakeholders.

Notwithstanding, this study is not without its limitations. We examined tourist engagement in the context of the Kinabalu National Park; as such, this may be considered as one of the limitation of this study. Further studies need to be conducted to test and validate the composite nature of tourist engagement in different contexts. In addition, we only examined the effects of this construct on satisfaction and loyalty. Further studies should assess and reexamine the antecedents and consequences of tourist engagement modeled as a second-order composite and 
compare the results against those of previous studies considering tourist engagement as a unidimensional, or multidimensional reflective construct. 


\section{References}

Ali, F., Rasoolimanesh, S. M., Sarstedt, M., Ringle, C. M., \& Ryu, K. (2018). An assessment of the use of partial least squares structural equation modeling (PLS-SEM) in hospitality research. International Journal of Contemporary Hospitality Management, 30(1), 514-538. https://doi.org/10.1108/IJCHM-10-2016-0568

Aguirre-Urreta, M.I. and Rönkkö, M. (in press). Statistical inference with PLSc using bootstrap confidence intervals, MIS Quarterly, available at: https://misq.org/forthcoming/?SID=kjm9t850mj6ah2v00hgutnc614

Bagozzi, R. P., \& Dholakia, U. M. (2006). Antecedents and purchase consequences of customer participation in small group brand communities. International Journal of Research in Marketing, 23(1), 45-61. https://doi.org/10.1016/j.ijresmar.2006.01.005

Bollen, K. A. (1989). Structural equations with latent variables. New York: J.

Bollen, K. A. (2011). Evaluating effect, composite, and causal indicators in structural equation models. Mis Quarterly, 359-372.

Bolton, R. N. (2011). Comment: customer engagement: opportunities and challenges for organizations. Journal of Service Research, 14(3), 272-274. https://doi.org/10.1177/1094670511414582

Bowden, J. L.-H. (2009). The process of customer engagement: A conceptual framework. The Journal of Marketing Theory and Practice, 17(1), 63-74. https://doi.org/10.2753/MTP10696679170105

Brodie, R. J., Hollebeek, L. D., Jurić, B., \& Ilić, A. (2011). Customer engagement: Conceptual domain, fundamental propositions, and implications for research. Journal of Service Research, 14(3), 252-271. https://doi.org/10.1177/1094670511411703

Brodie, R. J., Ilic, A., Juric, B., \& Hollebeek, L. (2013). Consumer engagement in a virtual brand community: An exploratory analysis. Journal of Business Research, 66(1), 105-114. https://doi.org/10.1016/j.jbusres.2011.07.029 
Bryce, D., Curran, R., O'Gorman, K., \& Taheri, B. (2015). Visitors' engagement and authenticity: Japanese heritage consumption. Tourism Management, 46, 571-581. https://doi.org/10.1016/j.tourman.2014.08.012

Chi, C. G.-Q., \& Qu, H. (2008). Examining the structural relationships of destination image, tourist satisfaction and destination loyalty: An integrated approach. Tourism Management, 29(4), 624-636. https://doi.org/10.1016/j.tourman.2007.06.007

Cohen, J. (1988). Statistical power analysis for the behavioral sciences (2nd ed.). Hillsdale, NJ: Lawrence Erlbaum Associates.

Diamantopoulos, A. (2006). The error term in formative measurement models: interpretation and modeling implications. Journal of Modelling in Management, 1(1), 7-17. https://doi.org/10.1108/17465660610667775

Diamantopoulos, A. (2008). Formative indicators: Introduction to the special issue. Journal of Business Research, 61(12), 1201-1202.

Dijkstra, T. K., \& Henseler, J. (2015a). Consistent and asymptotically normal PLS estimators for linear structural equations. Computational Statistics \& Data Analysis, 81, 10-23.

Dijkstra, T. K., \& Henseler, J. (2015b). Consistent Partial Least Squares Path Modeling. MIS Quarterly, 39(2), 297-316.

Faul, F., Erdfelder, E., Buchner, A., \& Lang, A.-G. (2009). Statistical power analyses using G*Power 3.1: Tests for correlation and regression analyses. Behavior Research Methods, 41(4), 11491160. https://doi.org/10.3758/BRM.41.4.1149

Fornell, C., \& Larcker, D. F. (1981). Evaluating structural equation models with unobservable variables and measurement error. Journal of Marketing Research, XVIII, 39-50.

Franke, G. \& Sarstedt, M. (in press). Heuristics versus statistics in discriminant validity testing: A comparison of four procedures. Internet Research.

Gallarza, M. G., \& Saura, I. G. (2006). Value dimensions, perceived value, satisfaction and loyalty: An investigation of university students' travel behaviour. Tourism Management, 27(3), 437452. https://doi.org/10.1016/j.tourman.2004.12.002 
Hair, J. F., Hult, G. T. M., Ringle, C., \& Sarstedt, M. (2017). A primer on partial least squares structural equation modeling (PLS-SEM) (2nd ed.). Thousand Oaks, CA: SAGE Publications.

Henseler, J., Müller, T., \& Schuberth, F. (2018). New guidelines for the use of PLS path modeling in hospitality, travel and tourism research. In F. Ali., S.M. Rasoolimanesh, \& C. Cobanoglu (Eds), Application of partial least squares: Structural equation modeling (PLS-SEM) in tourism and hospitality research (pp.17-33). Emerald Publishing Group.

Henseler, J. (2018). Partial least squares path modeling: Quo vadis?. Quality \& Quantity, 52(1), 1-8.

Henseler, J. (2017). Bridging design and behavioral research with variance-based structural equation modeling. Journal of Advertising, 46(1), 178-192. https://doi.org/10.1080/00913367.2017.1281780

Henseler, J., Hubona, G., \& Ray, P. A. (2016). Using PLS path modeling in new technology research: Updated guidelines. Industrial Management \& Data Systems, 116(1), 2-20. https://doi.org/10.1108/IMDS-09-2015-0382

Henseler, J., Ringle, C. M., \& Sarstedt, M. (2015). A new criterion for assessing discriminant validity in variance-based structural equation modeling. Journal of the Academy of Marketing Science, 43(1), 115-135. https://doi.org/10.1007/s11747-014-0403-8

Henseler, J. and Dijkstra, T.K. (2015), “ADANCO 2.0”, Composite Modeling, Kleve, available at:www.compositemodeling.com

Henseler, J., Dijkstra, T. K., Sarstedt, M., Ringle, C. M., Diamantopoulos, A., Straub, D. W., ... \& Calantone, R. J. (2014). Common beliefs and reality about PLS: Comments on Rönkkö and Evermann (2013). Organizational Research Methods, 17(2), 182-209.

Hollebeek, L. (2011). Exploring customer brand engagement: Definition and themes. Journal of Strategic Marketing, 19(7), 555-573. https://doi.org/10.1080/0965254x.2011.599493

Hu, L. T., \& Bentler, P. M. (1999). Cutoff criteria for fit indexes in covariance structure analysis: Conventional criteria versus new alternatives. Structural Equation Modeling: A Multidisciplinary Journal, 6(1), 1-55. 
Leckie, C., Nyadzayo, M. W., \& Johnson, L. W. (2016). Antecedents of consumer brand engagement and brand loyalty. Journal of Marketing Management, 32(5-6), 558-578. https://doi.org/10.1080/0267257X.2015.1131735

Lin, A., Gregor, S., \& Ewing, M. (2008). Developing a scale to measure the enjoyment of Web experiences. Journal of Interactive Marketing, 22(4), 40-57. https://doi.org/10.1002/dir.20120

Muniz, A. M., \& O’Guinn, T. C. (2001). Brand community. Journal of Consumer Research, 27(4), 412-432. https://doi.org/10.1086/319618

Müller, T., Schuberth, F., \& Henseler, J. (2018). PLS path modeling - a confirmatory approach to study tourism technology and tourist behavior. Journal of Hospitality and Tourism Technology, 9(3), 249-266.

Nitzl, C., Roldan, J. L., \& Cepeda, G. (2016). Mediation analysis in partial least squares path modeling: Helping researchers discuss more sophisticated models. Industrial Management \& Data Systems, 116(9), 1849-1864. https://doi.org/10.1108/IMDS-07-2015-0302

Oliver, R. L. (1999). Whence consumer loyalty? Journal of Marketing, 63(Special Issue), 33. https://doi.org/10.2307/1252099

Patterson, P., Yu, T., \& de Ruyter, K. (2006). Understanding customer engagement in services. In Advancing theory, maintaining relevance: Proceedings of ANZMAC 2006 conference (pp. 46). Brisbane, Queensland: Australia and New Zealand Marketing Academy Conference.

Rasoolimanesh, S. M., \& Ali, F. (2018). Partial least squares - structural equation modeling in hospitality and tourism. Journal of Hospitality and Tourism Technology, 9(3), 238-248.

Rasoolimanesh, S. M., Jaafar, M., Kock, N., \& Ahmad, A. G. (2017). The effects of community factors on residents' perceptions toward World Heritage Site inscription and sustainable tourism development. Journal of Sustainable Tourism, 25(2), 198-216. https://doi.org/10.1080/09669582.2016.1195836

Rasoolimanesh, S. M., Jaafar, M., \& Tangit, T. M. (2018). Community involvement in rural tourism: A case of Kinabalu National Park, Malaysia. Anatolia, 29(3), 337-350. https://doi.org/10.1080/13032917.2017.1412327 
Rothbard, N. P. (2001). Enriching or depleting? The dynamics of engagement in work and family roles. Administrative Science Quarterly, 46(4), 655. https://doi.org/10.2307/3094827

Sarstedt, M., Hair, J. F., Ringle, C. M., Thiele, K. O., \& Gudergan, S. P. (2016). Estimation issues with PLS and CBSEM: Where the bias lies! Journal of Business Research, 69(10), 39984010. https://doi.org/10.1016/j.jbusres.2016.06.007

Schaufeli, W. B., Salanova, M., González-Romá, V., \& Bakker, A. B. (2002). The measurement of engagement and burnout: A two sample confirmatory factor analytic approach. Journal of Happiness Studies, 3(1), 71-92. https://doi.org/10.1023/A:1015630930326

Schuberth, F., Henseler, J., \& Dijkstra, T. K. (2018). Confirmatory composite analysis. Frontiers in psychology, 9, 1-14.

Scholer, A. A., \& Higgins, E. T. (2009). Exploring the complexities of value creation: The role of engagement strength. Journal of Consumer Psychology, 19(2), 137-143. https://doi.org/10.1016/j.jcps.2009.02.007

So, K. K. F., King, C., \& Sparks, B. (2014). Customer engagement with tourism brands: Scale development and validation. Journal of Hospitality \& Tourism Research, 38(3), 304-329. https://doi.org/10.1177/1096348012451456

So, K. K. F., King, C., Sparks, B. A., \& Wang, Y. (2016). The role of customer engagement in building consumer loyalty to tourism brands. Journal of Travel Research, 55(1), 64-78. https://doi.org/10.1177/0047287514541008

Taheri, B., Jafari, A., \& O’Gorman, K. (2014). Keeping your audience: Presenting a visitor engagement scale. Tourism Management, 42, 321-329. https://doi.org/10.1016/j.tourman.2013.12.011

van Riel, A. C. R., Henseler, J., Kemény, I., \& Sasovova, Z. (2017). Estimating hierarchical constructs using consistent partial least squares: The case of second-order composites of common factors. Industrial Management \& Data Systems, 117(3), 459-477. https://doi.org/10.1108/IMDS-07-2016-0286

Vivek, S. D. (2009). A scale of consumer engagement (Doctoral dissertation). University of Alabama, Tuscaloosa, AL. 
Vivek, S. D., Beatty, S. E., \& Morgan, R. M. (2012). Customer engagement: Exploring customer relationships beyond purchase. The Journal of Marketing Theory and Practice, 20(2), 122146. https://doi.org/10.2753/MTP1069-6679200201

Voorhees, C. M., Brady, M. K., Calantone, R., \& Ramirez, E. (2016). Discriminant validity testing in marketing: an analysis, causes for concern, and proposed remedies. Journal of the Academy of Marketing Science, 44(1), 119-134. https://doi.org/10.1007/s11747-015-0455-4

Wold H. (1985). Partial Least Squares." In S Kotz, NL Johnson (eds.), Encyclopedia of Statistical Sciences, volume 6, (pp. 581-591). New York: John Wiley \& Sons.

Yoon, Y., \& Uysal, M. (2005). An examination of the effects of motivation and satisfaction on destination loyalty: A structural model. Tourism Management, 26(1), 45-56. https://doi.org/10.1016/j.tourman.2003.08.016

Zhou, Q. (Bill), Zhang, J., \& Edelheim, J. R. (2013). Rethinking traditional Chinese culture: A consumer-based model regarding the authenticity of Chinese calligraphic landscape. Tourism Management, 36(1), 99-112. https://doi.org/10.1016/j.tourman.2012.11.008 
Figure 1: Conceptual framework

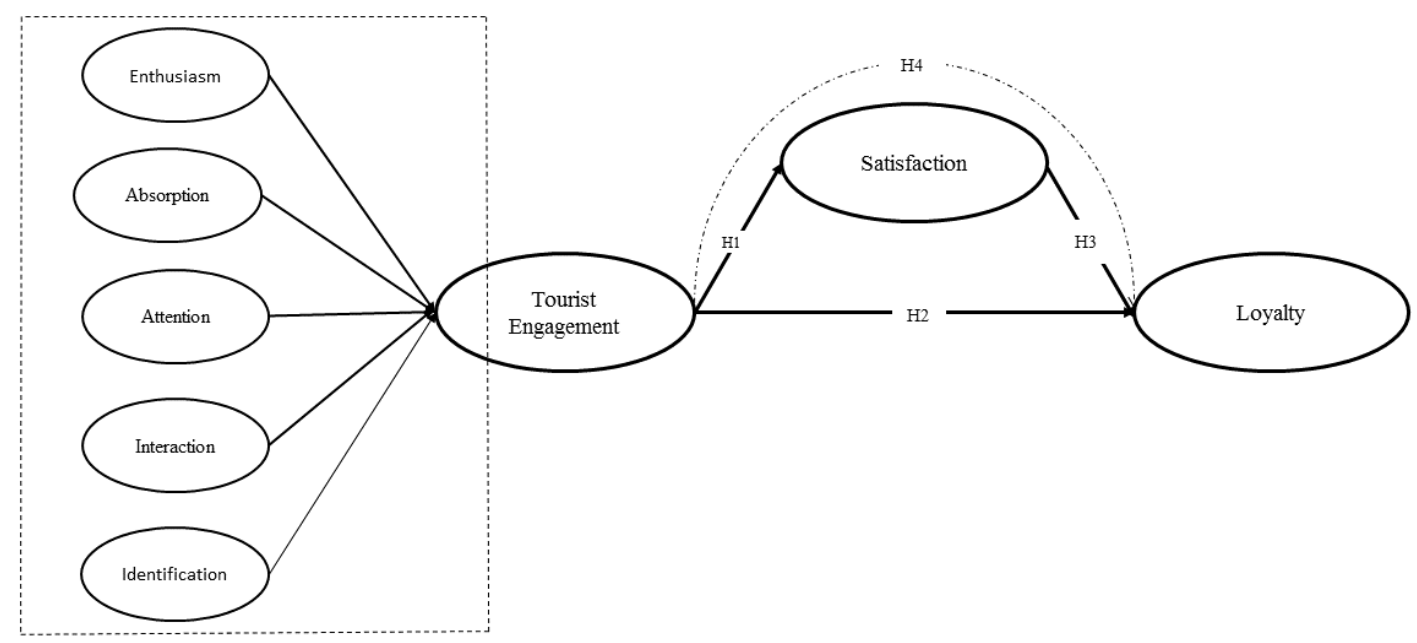

Note: Solid arrows show direct effects, and the dashed arrow shows the indirect effect.

Figure 2: Model containing the second-order composite

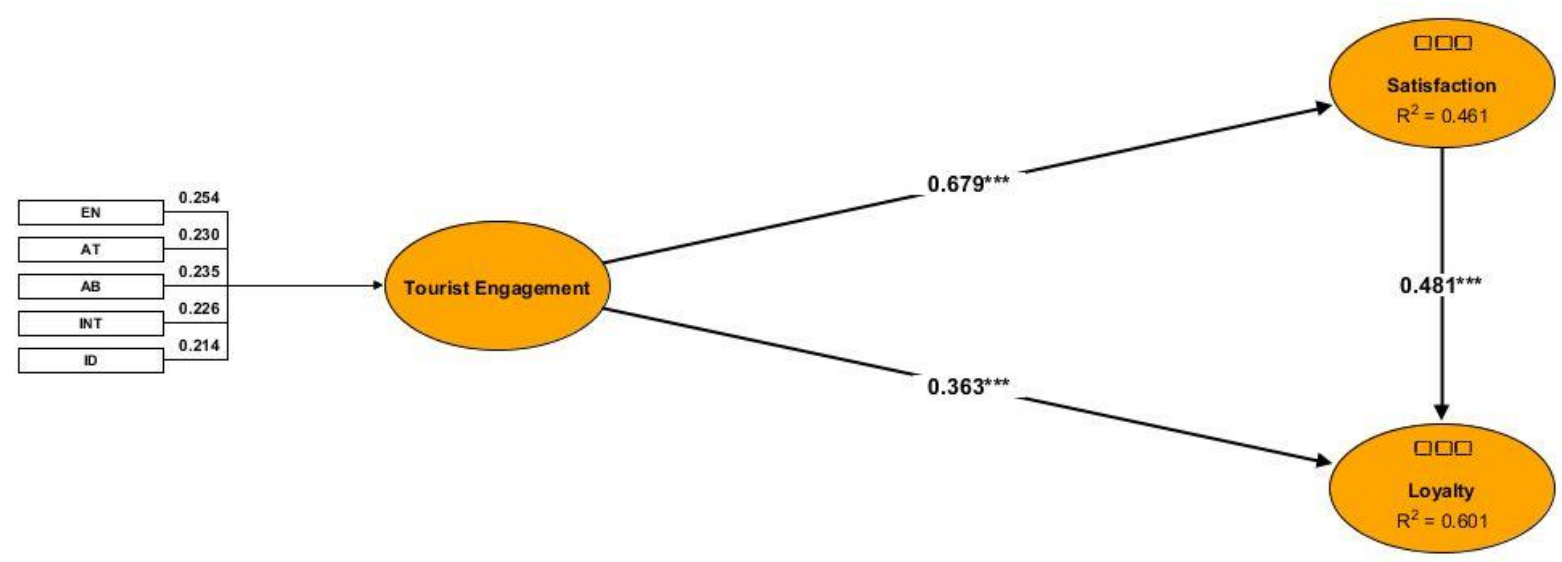


Table 1. Results for the assessment of reflective measurement and composite models

\begin{tabular}{|c|c|c|c|c|c|c|c|}
\hline Construct & Items & Type & $\begin{array}{c}\text { Loadings/ } \\
\text { Weights }\end{array}$ & CR & $\begin{array}{l}\text { Cronbach's } \\
\text { Alpha }\end{array}$ & rho A & AVE \\
\hline \multirow{4}{*}{ Enthusiasm } & & Reflective & & 0.927 & 0.9270 & 0.928 & 0.810 \\
\hline & EN1 & & 0.873 & & & & \\
\hline & EN2 & & 0.923 & & & & \\
\hline & EN3 & & 0.904 & & & & \\
\hline \multirow[t]{4}{*}{ Attention } & & Reflective & & 0.874 & 0.874 & 0.874 & 0.697 \\
\hline & AT1 & & 0.843 & & & & \\
\hline & AT2 & & 0.846 & & & & \\
\hline & AT3 & & 0.816 & & & & \\
\hline \multirow[t]{5}{*}{ Absorption } & & Reflective & & 0.898 & 0.897 & 0.902 & 0.689 \\
\hline & $\mathrm{AB} 1$ & & 0.795 & & & & \\
\hline & $\mathrm{AB} 2$ & & 0.909 & & & & \\
\hline & $\mathrm{AB} 3$ & & 0.847 & & & & \\
\hline & $\mathrm{AB} 4$ & & 0.761 & & & & \\
\hline \multirow{4}{*}{ Interaction } & & Reflective & & 0.873 & 0.874 & 0.874 & 0.696 \\
\hline & IN1 & & 0.815 & & & & \\
\hline & IN2 & & 0.809 & & & & \\
\hline & IN3 & & 0.877 & & & & \\
\hline \multirow[t]{4}{*}{ Identification } & & Reflective & & 0.868 & 0.867 & 0.871 & 0.688 \\
\hline & ID1 & & 0.770 & & & & \\
\hline & ID2 & & 0.854 & & & & \\
\hline & ID3 & & 0.862 & & & & \\
\hline \multirow[t]{4}{*}{ Satisfaction } & & Reflective & & 0.915 & 0.915 & 0.916 & 0.782 \\
\hline & SAT1 & & 0.907 & & & & \\
\hline & SAT2 & & 0.885 & & & & \\
\hline & SAT3 & & 0.860 & & & & \\
\hline \multirow[t]{4}{*}{ Loyalty } & & Reflective & & 0.882 & 0.882 & 0.883 & 0.715 \\
\hline & LOY1 & & 0.808 & & & & \\
\hline & LOY2 & & 0.864 & & & & \\
\hline & LOY3 & & 0.863 & & & & \\
\hline \multirow[t]{6}{*}{ Tourist Engagement } & & Composite & & NA & NA & NA & NA \\
\hline & Enthusiasm & & 0.215 & & & & \\
\hline & Attention & & 0.247 & & & & \\
\hline & Absorption & & 0.199 & & & & \\
\hline & Interaction & & 0.234 & & & & \\
\hline & Identificati & & 0.214 & & & & \\
\hline
\end{tabular}

Note: the weights differs from those displayed in Figure 2 as they were corrected for attenuation. 
Table 2: Discriminant validity assessment of the constructs modeled as common factor (Fornell-Larcker criterion)

\begin{tabular}{c|ccccccc}
\hline & Enthusiasm & Attention & Absorption & Interaction & Identification & Satisfaction & Loyalty \\
\hline Enthusiasm & $\mathbf{0 . 8 1 0}$ & & & & & & \\
Attention & 0.554 & $\mathbf{0 . 6 9 8}$ & & & & & \\
Absorption & 0.502 & 0.765 & $\mathbf{0 . 6 8 9}$ & & & & \\
Interaction & 0.586 & 0.628 & 0.687 & $\mathbf{0 . 6 9 6}$ & & & \\
Identification & 0.612 & 0.525 & 0.405 & 0.600 & $\mathbf{0 . 6 8 8}$ & & \\
Satisfaction & 0.411 & 0.476 & 0.472 & 0.385 & 0.301 & $\mathbf{0 . 7 8 2}$ & $\mathbf{0 . 7 1 5}$ \\
Loyalty & 0.564 & 0.372 & 0.383 & 0.429 & 0.437 & 0.655 & \\
\hline
\end{tabular}

Note: Off-diagonal elements present squared correlations; average variances extracted (AVEs) are shown on diagonal in bold.

Table 3: Discriminant validity assessment of the constructs modeled as common factors (HTMT)

\begin{tabular}{c|ccccccc}
\hline & Enthusiasm & Attention & Absorption & Interaction & Identification & Satisfaction & Loyalty \\
\hline Enthusiasm & & & & & & & \\
Attention & 0.745 & & & & & & \\
Absorption & 0.708 & 0.875 & 0.790 & 0.829 & & & \\
Interaction & 0.765 & 0.790 & 0.636 & 0.777 & & \\
Identification & 0.782 & 0.724 & 0.689 & 0.616 & 0.550 & \\
Satisfaction & 0.642 & 0.690 & 0.619 & 0.655 & 0.662 & 0.812 \\
Loyalty & 0.751 & 0.609 & & & & \\
\hline
\end{tabular}


Table 4: Results of the structural model

\begin{tabular}{ll|ccccc}
\hline \multicolumn{1}{c}{ Hypothesis } & $\begin{array}{c}\text { Direct/Indirect } \\
\text { Effect }\end{array}$ & $\boldsymbol{t}$ - value & $\begin{array}{c}\text { Confidence Interval } \\
\text { (Percentile } \\
\text { Bootstrap) }\end{array}$ & $\begin{array}{c}\text { Effect } \\
\text { size } \\
\left(\boldsymbol{f}^{2}\right)\end{array}$ & Supported \\
\hline H1 & TE $\rightarrow$ SAT & 0.679 & 10.972 & {$[0.660,0.842]$} & 0.857 & YES \\
H2 & TE $\rightarrow$ LOY & 0.363 & 5.440 & {$[0.140,0.382]$} & 0.178 & YES \\
H3 & SAT $\rightarrow$ LOY & 0.481 & 6.535 & {$[0.469,0.737]$} & 0.313 & YES \\
H4 & TE $\rightarrow$ SAT $\rightarrow$ LOY & 0.327 & 6.032 & {$[0.363,0.581]$} & NA & YES \\
\hline
\end{tabular}


Appendix 1. List of items

\begin{tabular}{|l|l|}
\hline & Questions \\
\hline & Enthusiasm \\
\hline EN1 & I am heavily into this tourism site. \\
\hline EN2 & I am passionate about this tourism site. \\
\hline EN3 & I am enthusiastic about this tourism site. \\
\hline & Attention \\
\hline AT1 & I pay a lot of attention to anything about this tourism site. \\
\hline AT2 & Anything related to this tourism site grabs my attention. \\
\hline AT3 & I concentrate a lot in my visit at this tourism site. \\
\hline & Absorption \\
\hline AB1 & When I am interacting with the tourism site, I forget everything else around me. \\
\hline AB2 & Time flies when I am interacting with the tourism site. \\
\hline AB3 & When I am interacting with the tourism site, I get carried away. \\
\hline AB4 & When interacting with the tourism site, it is difficult to detach myself. \\
\hline & Interaction \\
\hline IN1 & I am someone who enjoys interacting with like-minded community in the tourism site \\
\hline IN2 & I am someone who likes to actively participate in the tourism site community discussions. \\
\hline IN3 & $\begin{array}{l}\text { In general, I thoroughly enjoy exchanging ideas with other people in the tourism site } \\
\text { community. }\end{array}$ \\
\hline & Identification \\
\hline ID1 & When someone criticizes this tourism site, it feels like a personal insult \\
\hline ID2 & $\begin{array}{l}\text { When I talk about this tourism site, I usually say 'we' rather than 'they' because the } \\
\text { identity of the site suites me. }\end{array}$ \\
\hline ID3 & When someone praises this tourism site, it feels like a personal compliment. \\
\hline & Satisfaction \\
\hline SAT1 & I think I made the right decision to visit the site. \\
\hline SAT2 & I am satisfied with my overall experience during my visit. \\
\hline SAT3 & My choice to visit this tourism site was a wise one. \\
\hline & Loyalty \\
\hline LOY1 & I would recommend this tourism site to someone who seeks my advice. \\
\hline LOY3 & I would encourage friends and relatives to do business with this tourism site. \\
\hline & \\
\hline
\end{tabular}

